\title{
Growth Performance Comparisons among 18 Accessions of Fourwing Saltbush [Atri- plex canescens] at Two Sites in Central Utah
}

\author{
E. DURANT MCARTHUR, RICHARD STEVENS, AND A. CLYDE BLAUER
}

\begin{abstract}
Growth characteristics of 17 accessions and 1 selection of fourwing saltbush (Atriplex canescens [Pursh] Nutt.) at 2 sites in Sanpete Valley, central Utah, were scored on 6-year-old mature plants. There was no difference in survival at the 2 sites, but plants at the Snow Field Station near Ephraim grew taller, were more vigorous, and exhibited more reproductive capacity than those at the Peacock Plot near Manti. The plants at Peacock Plot had a more upright growth habit, were more uniform, and exhibited less insect and disease damage than the Snow Field Station plants. A composite quality index (QI) revealed highly significant site and accession differences but little site $X$ accession interaction. The individual traits (height, growth habit, uniformity, vigor, reproduction, and insect and disease damage resistance) all showed significant site effects and site $\times$ accession interaction. An accession and its selection from Rincon Blanco, Rio Arriba County, New Mexico, performed well at both sites. Also performing well at both sites were a local accession from Excell Canyon, Sanpete County, Utah, and the gigas accession from the Little Sahara Sand Dunes, Juab County, Utah. In general, accessions from elevations higher than the test sites performed best. Accessions with high QI's are recommended for revegetation plantings of sites comparable to the 2 study sites. The Rincon Blanco material has good growth characteristics and may also be broadly adapted.
\end{abstract}

Fourwing saltbush (Atriplex canescens [Pursh] Nutt.) is widely used in land rehabilitation plantings because it establishes well, grows rapidly, is broadly adapted, is excellent wildlife and livestock forage, and grows well with other plants (Plummer et al. 1966, Blauer et al. 1976, Van Epps and McKell 1977, McArthur et al. 1978a, Goodin 1979). The species shows considerable interaccessional variation in several characteristics (Table 1). Withinaccessional variation is also documented (Crofts 1977, Gerard 1978, McArthur et al. 1978b, Welch and Monsen 1981). In this note, we report performance characteristics of 18 accessions ${ }^{1}$ including 1 selection at 2 contrasting sites in Sanpete County, central Utah. These accessions were originally from 5 states at elevations ranging from 1,420 to $2,400 \mathrm{~m}$ and latitudes from $36-41^{\circ}$ $\mathbf{N}$ (Table 2). The selection was included inasmuch as some prelimi-

The authors are: principal research geneticist, Intermountain Forest and Range Experiment Station, Ogden, Utah 84401 , stationed at the Shrub Sciences Laboratory, Provo, Utah 84601; wildlife biologist, Utah Division of Wildlife Resources, Great Basin Fxperimental Area, Ephraim, Utah 84627: and associa te professor of biology. Snow College, Ephraim, Utah 84627. E.D. McArthur is also adjunct professor of botany and range science at Brigham Young University. A.C. Blauer has been a botanist for the Intermountain Station for several summers.

Federal funds for wildlife restoration were provided through Pittman-Robertson Project W-82-R (Cooperators: Intermountain Forest and Range Experiment Station of USDA Forest Service and the Utah Division of Wildlife Resources). The Snow Field Station is cooperatively maintained by the above 2 agencies. Utah State University and Snow College. The Peacock Plot is maintained by the Utah Division of Wildlife Resources. We thank Drs. D.C. Freeman, W.G. Hassell, and G.L. Noller for technical advice.

Manuscript received September 28, 1981

nary tests indicated its superior performance (McArthur et al. 1978b).

\section{Sites}

The 2 sites are located $15 \mathrm{~km}$ apart, west of the monoclinal western front of the Wasatch Plateau in Sanpete County, Utah. Both sites are at $1,700 \mathrm{~m}$ elevation. The Snow Field Station site, northeast of Ephraim, has a deep limestone-derived clay soil with a pH of 8.6. The Peacock Plot site, south of Manti, is located on a small alluvial fan derived from shale and limestone. It has a loamy soil with mixed pebbles and stones and a $\mathrm{pH}$ of 7.9 Both sites originally supported basin big sagebrush-bluebunch wheatgrass vegetation types that were later converted to agricultural use. The Snow Field Station received an average of $23.8 \mathrm{~cm}$ precipitation during the study period (1980); the Peacock Plot site received 30.4 $\mathrm{cm}$. Long-term a verage precipitation is $27.1 \mathrm{~cm}$ for the Snow Field Station and $31.1 \mathrm{~cm}$ for Peacock Plot. Approximately half the precipitation at both sites comes in the winter (November 12-April 30), mostly as snow (McArthur and Welch 1982).

\section{Methods}

Plants were established by seeding $1.5-\mathrm{m}$ row blocks $0.7 \mathrm{~m}$ apart, in fall 1974. The rows were irrigated in 1975 to aid in establishment

Table 1. Characteristics of fourwing saltbush which show variability between sites or a ccessions.

\begin{tabular}{ll}
\hline Characteristic & References \\
\hline Soil salinity & Northington and Goodin 1975; \\
& Welch 1978; Richardson and McKell \\
& 1980.
\end{tabular}

Ash content

Welch 1978.

Crude protein

Stem rooting

Gamrath 1972; Welch 1978; Welch and Monsen 1981.

Palatability

Winter hardiness

Seed production, fill, and germination

Sex expression

Chromosome number

Growth rate and form
Van Epps and McKell 1978; Richardson et al. 1979.

Van Epps 1975a; Van Epps, data on file at Snow Field Station

Van Epps 1975b; Kay et al. 1977.

Plummer et al. 1966; Springfield 1970; Gamrath 1972; Stutz et al. 1975; Gerard 1978.

Stutz et al. 1975; McArthur 1977; McArthur and Freeman, in press.

Stutz et al. 1975; Stutz and Sanderson 1979.

Plummer et al. 1966; Stutz et al. 1975. 
but have not been irrigated since. The accessional performances (Table 2) were scored in 1980 . Percent survival was determined by giving each plot a score of 100 if at least 3 or more plants survived, 67 if 2 survived, 33 if 1 survived, and 0 if there were no survivors. In a $1.5-\mathrm{m}$ row, 3 plants easily occupy all the space. Then all row plots (range $=2-19$ ) at each site were averaged to give the survival value for each accession. The survival value of Table 2 is the mean for both sites. For all other characteristics, 5 plants (but no more than
3 per plot) were picked by random means for each site. The characteristics selected included some of those used in an earlier study (McArthur et al. 1978b): maximum height $(\mathrm{cm})$, which correlates well with other biomass characteristics (McArthur et al. 1978b); growth habit (prostrate $=1$; decumbent $=2$; diffuse $=3$; erect $=4$ ); uniformity (sparse, uneven foliage $=1$; dense, even foliage $=9)$; vigor $(1=$ nearly dead; $9=$ high $)$; reproduction $(0=$ no seed or pollen produced; $(9=$ heavy seed or pollen production);

Table 2. Summary of performance of 18 accessions of Atriplex canescens at 2 central Utah sites.

\begin{tabular}{|c|c|c|c|c|c|c|c|c|c|c|}
\hline \multirow[b]{3}{*}{ Accession 1} & \multicolumn{10}{|c|}{ Performance trait } \\
\hline & \multirow[b]{2}{*}{ Survival } & \multirow[b]{2}{*}{ Height } & \multirow[b]{2}{*}{$\begin{array}{l}\text { Growth } \\
\text { form }\end{array}$} & \multirow[b]{2}{*}{$\begin{array}{c}\text { Uni- } \\
\text { formity }\end{array}$} & \multirow[b]{2}{*}{ Vigor } & \multirow{2}{*}{$\begin{array}{l}\text { Repro- } \\
\text { duction }\end{array}$} & \multirow{2}{*}{$\begin{array}{l}\text { Insect and } \\
\text { disease } \\
\text { resistance }\end{array}$} & \multicolumn{3}{|c|}{ Quality index ${ }^{2}$} \\
\hline & & & & & & & & Mean & Ranks & $\begin{array}{l}\text { Signifi- } \\
\text { cance }\end{array}$ \\
\hline Rincon Blanco selection (U103p) & $\begin{array}{r}(\%) \\
90\end{array}$ & $\begin{array}{l}(\mathrm{cm}) \\
133\end{array}$ & 3.6 & 6.7 & 6.9 & 5.9 & 8.0 & $82.2 \pm 4.7$ & 1,2 & a \\
\hline $\begin{array}{l}\text { Rincon Blanco, Rio Arriba Co., } \\
\text { New Mexico (U92) } 2400 \mathrm{~m} 36^{\circ} 30^{\prime}\end{array}$ & 85 & 135 & 3.8 & 6.6 & 6.5 & 5.4 & 7.9 & $81.6 \pm 4.8$ & 3,1 & $\mathbf{a b}$ \\
\hline $\begin{array}{l}\text { Jericho, Juab Co., Utah } \\
\text { (U88) } 1600 \mathrm{~m} 39^{\circ} 40^{\prime}\end{array}$ & 84 & 132 & 3.9 & 5.0 & 5.5 & 4.1 & 8.0 & $75.4 \pm 7.5$ & 2,8 & abe \\
\hline $\begin{array}{l}\text { Excell Canyon. Sanpete Co., Utah } \\
\text { (U36) } 1830 \mathrm{~m} 39^{\circ} 20^{\prime}\end{array}$ & 72 & 117 & 3.3 & 6.9 & 6.9 & 5.1 & 6.4 & $75.4 \pm 3.9$ & 9.3 & $a b c$ \\
\hline $\begin{array}{l}\text { Keams Canyon, Navajo Co., Arizona } \\
\text { (U72) } 1920 \mathrm{~m} 35^{\circ} 50^{\prime}\end{array}$ & 96 & 114 & 3.2 & 6.3 & 6.4 . & 5.0 & 7.9 & $73.8 \pm 2.6$ & 11,4 & abc \\
\hline $\begin{array}{l}\text { Mayfield, Sanpete Co., Utah } \\
\text { (U81) } 1740 \mathrm{~m} 39^{\circ} 06^{\prime}\end{array}$ & 92 & 109 & 3.7 & 6.3 & 6.0 & 4.0 & 8.0 & $72.6 \pm 5.8$ & 16,5 & abc \\
\hline $\begin{array}{l}\text { Manila, Dagget Co., Utah (U51) } \\
2080 \mathrm{~m} 41^{\circ} 00^{\prime}\end{array}$ & 92 & 114 & 3.6 & 6.3 & 6.2 & 3.4 & 7.5 & $70.7 \pm 5.3$ & 6,12 & $a b c$ \\
\hline $\begin{array}{l}\text { Cougar Spar, Beaver Co, Utah } \\
\text { (U143) } 2230 \mathrm{~m} 38^{\circ} 10^{\prime}\end{array}$ & 92 & 86 & 3.3 & 6.8 & 6.5 & 7.0 & 8.2 & $70.6 \pm 2.7$ & 13,6 & abc \\
\hline $\begin{array}{l}\text { Black Mountain, Sevier Co., Utah } \\
\text { (U43) } 1900 \mathrm{~m} 38^{\circ} 50^{\prime}\end{array}$ & 67 & 106 & 3.2 & 6.6 & 6.3 & 4.6 & 8.0 & $70.4 \pm 4.2$ & 15,7 & $a b c$ \\
\hline $\begin{array}{l}\text { Tuba City, Coconino Co., Arizona } \\
\text { (U54) } 1520 \mathrm{~m} 36^{\circ} 08^{\prime}\end{array}$ & 92 & 112 & 3.6 & 6.1 & 5.6 & 3.5 & 6.8 & $69.5 \pm 4.0$ & 10,10 & abcd \\
\hline $\begin{array}{l}\text { Kingston, Piute Co., Utah (U85) } \\
1940 \mathrm{~m} 38^{\circ} 10^{\prime}\end{array}$ & 92 & 101 & 3.7 & 5.8 & 6.1 & 4.3 & 8.0 & $69.0 \pm 4.7$ & 7,13 & abcd \\
\hline 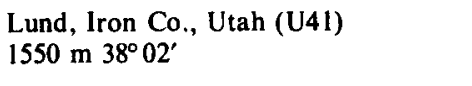 & 80 & 103 & 3.3 & 6.8 & 5.7 & 4.6 & 7.9 & $69.0 \pm 4.7$ & 12,9 & abcd \\
\hline $\begin{array}{l}\text { Kanab, Kane Co., Utah (U86) } \\
1520 \mathrm{~m} 37^{\circ} 02^{\prime}\end{array}$ & 100 & 108 & 3.9 & 5.3 & 5.5 & 3.8 & 7.9 & $68.9 \pm 5.8$ & 4,16 & abcd \\
\hline $\begin{array}{l}\text { Delta, Delta Co., Colorado } \\
\text { (U74) } 1520 \mathrm{~m} 38^{\circ} 40^{\prime}\end{array}$ & 72 & 98 & 3.6 & 6.8 & 5.9 & 3.7 & 7.8 & $67.6 \pm 4.9$ & 8,16 & bcd \\
\hline $\begin{array}{l}\text { Panaca, Lincoln Co., Nevada (U77) } \\
1420 \mathrm{~m} 37^{\circ} 40^{\prime}\end{array}$ & 84 & 92 & 3.6 & 6.1 & 5.5 & 4.1 & 8.0 & $65.3 \pm 6.8$ & 5,18 & cd \\
\hline $\begin{array}{l}\text { Milford, Beaver Co., Utah (U I58) } \\
\text { I520 m } 38^{\circ} 20^{\prime}\end{array}$ & 84 & 90 & 3.5 & 6.6 & 5.1 & 3.8 & 7.8 & $63.6 \pm 3.2$ & 17,11 & cd \\
\hline $\begin{array}{l}\text { American Fork, Utah Co., Utah } \\
\text { (U121) } 1520 \mathrm{~m} 40^{\circ} 24^{\prime}\end{array}$ & 75 & 95 & 3.2 & 5.7 & 5.1 & 3.6 & 8.1 & $62.0 \pm 5.6$ & 13,15 & cd \\
\hline $\begin{array}{l}\text { Desert Exp. Sta., Millard Co., Utah } \\
\text { (U 132) } 1620 \mathrm{~m} 38^{\circ} 37^{\prime}\end{array}$ & 100 & 69 & 3.4 & 6.0 & 4.6 & 4.6 & 7.5 & $55.3 \pm 3.3$ & 18,14 & cd \\
\hline $\begin{array}{l}\text { Site means: } \\
\text { Snow Field Station } \\
\text { PeacockPlot }\end{array}$ & $\begin{array}{l}83 \\
85\end{array}$ & $\begin{array}{r}128 \\
85\end{array}$ & $\begin{array}{l}3.3 \\
3.7\end{array}$ & $\begin{array}{l}5.9 \\
6.6\end{array}$ & $\begin{array}{l}6.3 \\
5.5\end{array}$ & $\begin{array}{l}5.8 \\
3.1\end{array}$ & $\begin{array}{l}7.5 \\
8.0\end{array}$ & $\begin{array}{l}77.8 \\
62.8\end{array}$ & - & \\
\hline $\begin{array}{l}\text { Significançe } \\
\text { Site } \\
\text { Accession } \\
\text { Interaction }\end{array}$ & $\begin{array}{l}\text { NS } \\
- \\
-\end{array}$ & $\begin{array}{l}* * \\
* * \\
*\end{array}$ & ** & 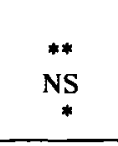 & $\stackrel{* *}{N S}$ & $\underset{* *}{* *}$ & ** & $\begin{array}{l}* * \\
* * \\
\text { NS }\end{array}$ & & \\
\hline
\end{tabular}

IAccession numbers of the $U$ series refer to the order the seed accessions were lotted at the Great Basin Experimental Area, Ephraim, Utah. Elevation and latitude ( $N$ ) of original collection sites are given.

2The mean QI are followed by standard errors of the mean. Ranks of Q1 are given first for the Snow Field Station and then for the Peacock Plot. Letters in significant column indicate significant rank differences $p<0.05$ among accessions when letters are not shared by the Duncan mean comparison test (Steele and Torrie 1960).

${ }^{3} \mathrm{NS}=$ not significant; ${ }^{*}=$ significant at $p<0.05 ;{ }^{* *}=$ significant at $p<0.01$. Survival compared by paired $t$-test and all other performance traits by ANOVAR. 
and insect and disease damage $(1=$ heavy damage; $9=$ no damage). We also did a quality index (QI) for each plant scored by using the formula: $\mathrm{QI}=-\frac{\text { height in } \mathrm{cm}}{150} \times 40+\frac{\text { growth habit score }}{4} \times 10$ $+\frac{\text { uniformity score }}{9} \times 10+\frac{\text { vigor score }}{9} \times 15+\frac{\text { reproductive score }}{9}$ $\times 15+\frac{\text { insect and disease damage score }}{9} \times 10$. A plant with consistently good scores could approach a QI of 100 . Plants taller than $150 \mathrm{~cm}$ could exceed a QI of 100 . The data were analyzed by using ANOVAR (Brigham Young University Computer Center) to perform completely crossed analysis of variance for all characteristics except percent survival. A paired $t$-test was used to compare survival between sites (Woolf 1968). Accessional means were compared by the Duncan multiple range test (Steele and Torrie 1960).

\section{Results and Discussion}

Our data (Table 2) reveal the accessions performed differently at the 2 sites. Every trait except percent survival showed a highly significant $(p<0.01)$ difference between the Snow Field Station and Peacock Plot sites. There was no difference in survival rates between sites. Height, vigor, reproduction, and QI were all better at the Snow Field Station; growth habit, uniformity, and resistance to insect and disease damage performances were superior at Peacock Plot. Not all the variation, however, can be accounted for by site or accession factors. Site $X$ accession interactions account for a significant part of the variation. There were significant accession $X$ site interactions for height, growth habit, uniformity, vigor, reproduction, and insect and disease damage (Table 2). We interpret these interactions to mean that the accessions perform differently at the two sites. The Snow Field Station is a good place to grow several kinds of shrubs. An earlier study showed several sagebrush accessions had superior growth rates there, in comparison to another experimental garden and the natural accessional sites (McArthur and Welch 1982). In the present experiment, fourwing saltbush grew faster and larger at Snow Field Station than at Peacock Plot. The Peacock Plot plants had a more upright and uniform growth habit that may be attributable to site conditions. The larger plants at the Snow Field Station exaggerate the presence of canopy gaps and lateral branches. Like height, vigor and reproduction were best at the Snow Field Station and indicate better overall plant growth conditions there. The larger, more vigorous plants at Snow Field Station may have been more inviting targets for insect and disease pests. In general, insect densities are higher at the Snow Field Station than Peacock Plot. Nevertheless, the case-bearing moth (Coleophora atriplicivora) has been found at both places. Symptoms of vascular tissue fungal disea ses (Verticillium sp., Rhizoctonia sp.) are present at both sites (Nelson, D.L., data on file, Shrub Sciences Laboratory).

The QI that incorporates all traits except survival proved to be particularly interesting. With this index, both site and accession components were highly significant, but their interaction was minimal. The selection U103p and its parent accession (U92) from Rincon Blanco, Rio Arriba County, N. Mex., had the highest Ql's because of their consistently high performance traits (Table 2). Both performed well at both study sites. Selection U 103 p ranked 1 and 2, and accession U92 ranked 3 and 1 at the Snow Field Station and Peacock Plot, respectively (Table 2). Two other accessions also maintained relatively high QI ranks at both sites: U88 from Little Sahara Sand Dunes near Jericho, Juab County, Utah; and U36 from Excell Canyon west of Ephraim, Sanpete County, Utah. The sand dune accession is the gigas diploid studied by Stutz et al. (1975). It grows much larger in some situations than at our sites. Still, it was one of the larger accessions in our study. The overall QI was reduced because its uniformity, vigor, and reproduction characteristics were relatively low. The high rankings of the Excell Canyon and Mayfield (U81) accessions support Van Epps'(1975b) recommendation that nearby seed sources are generally good for vegetative rehabilitation efforts. In our study, however, some accessions from distant places, particula rly from higher elevations, did well. The 8 best performing accessions, omitting the selection, had a mean original collection site elevation of $1,962 \mathrm{~m}$, whereas the lowest 9 had an elevational mean of $1.570 \mathrm{~m}$ (Table 2). Some fourwing saltbush accessions have broader areas of adaptation than others. The Rincon Blanco accession and its selection are apparently among these. We recommend these materials be tested more widely.

Some accessions had considerable individual plant variation. For example, the sand dune accession (U88) had QI ranges from 45-106 and the Manila accession (U151) from 54-105. The lowest QI was a 20, on the Panaca accession (U7), growing at Peacock Plot. Three of the 180 plants sampled had Ql's greater than 100:2 from Snow Field Station and 1 from Peacock Plot. The large variation reflects the outcrossing, principally dioecious, flowering habit of fourwing saltbush. Despite the species inherent variation, some accessions maintained QI rank consistencies between sites. There are significant differences among the accessional means (Table 2). In general, we recommend accessions with higher Q1 values for areas with environmental conditions similar to Sanpete Valley.

\section{Literature Cited}

Blauer, A.C., A.P. Plummer, E.D. McArthur, R. Stevens, and B.C. Giunta 1976. Characteristics and hybridization of important intermountain shrubs. II. Chenopod family. USDA-FS Res. Pap. INT-77.

Crofts, K.A. 1977. The importance of utricle-related factors in germination and seedling vigor of four species of perennial Atriplex. M.S. Thesis, Utah State Univ., Logan.

Gamrath, W.G. 1972. The relationship of plant morphology and seed processing to utricle fill and germination of fourwing saltbush (Atriplex canescens [Pursh] Nutt.) seed. M.S. Thesis, Montana State Univ., Bozeman.

Gerard, J.B. 1978. Factors affecting fruit fill and seed germination of fourwing saltbush (Atriplex canescens [Pursh] Nutt.) p. 403-405. In: Proc. First lnternat. Rangeland Congr. Hyder, D.N. (ad.). Soc. Range Manage., Denver, Colo.

Goodin, J.R. 1979. The forage potential of Atriplex canescens. p. 418-424. In: Arid land plant resources, Goodin, J.R., and D.K. Northington (eds.). Internat. Center for Arid and Semiarid Land Studies, Texas Tech Univ., Lubbock.

Kay, B.L., C.R. Brown, and W.L. Graves. 1977. Mohave Valley revegetation notes. No. 17. Fourwing Saltbush. Univ. California, Davis.

McArthur, E.D. 1977. Environmentally induced changes of sex expression in Atriplex canescens. Heredity 38:97-103.

McArthur, E.D., and D.C. Freeman. In Press. Sex expression in Atriplex canescens: genetics and environment. Bot. Gaz.

Mc Arthur, E.D., A.P. Plummer, and J.N. Davis. 1978a. Rehabilitation of game ranges in the salt desert. p. 23-50. In: Wyoming Shrublands, Proc. Seventh Wyoming Shrub Ecology Workshop. Johnson, K.L. (ed.). Univ. Wyoming, Laramie.

McArthur, E.D., A.P. Plummer, G.A. Van Epps, D.C.Freeman, and K.R. Jorgensen. 1978b. Producing fourwing saltbush in seed orchards. p. 406-410. In: Proc. First Internat. Rangeland Cong. Hyder, D.N. (ed.). Soc. Range Manage., Denver, Colo.

McArthur, E.D., and B.L. Welch. 1982. Growth rate differences among big sagebrush (Artemisia tridentata) accessions and subspecies. J. Range manage. 35:396-40 I

Northington, D.K., and J.R. Goodin. 1975. Variability in natural populations of Atriplex canescens. p. 149. In: Proc., Symposium, and Workshop: Wildland Shrubs. Stutz, H.C. (ed.). Brigham Young Univ., Provo, Utah.

Plummer, A.P., S.B. Monsen, and D.R. Christensen. 1966. Fourwing saltbush, a shrub for future game ranges. Utah Dep. Fish and Game Publ. 66-4.

Richardson, S.G., J.R. Barker, K.A. Crofts, and G.A. Van Epps. 1979. Factors affecting root of stem cuttings of salt desert shrubs. J. Range Manage. 32:280-283.

Richardson, S.G., and C.M. McKell. 1980. Salt tolera nce of two saltbush species grown in processed oil shale. J. Range Manage. 32:280-283.

Springfield, H.W. 1970. Germination and establishment of fourwing saltbush in the Southwest. USDA-FS Res. Pap. RM-55. 
Steele, R.G.D., and J.H. Torrie. 1960. Principles and procedures of statistics. McGraw-Hill Book Company. New York.

Stutz, H.C., J.M. Melby, and G.K. Livingston. 1975. Evolutionary studies in Atriplex: a relic gigas diploid population of Atriplex canescens. Amer. J. Bot. 62:236-245.

Stutz, H.C., and S.C. Sanderson. 1979. The role of polyploidy in the evolution of Atriplex canescens. p. 615-621. In: Arid Land Plant Resources. Goodin, J.R., and D.K. Northington (eds). Intemat. Center for Arid and Semiarid Land Studies. Texas Tech Univ., Lubbock.

Van Epps, G.A. 1975a. Palatability of important shrubs grazed in late fall by sheep. Unpublished paper presented at Soc. Range Manage. 28th Annual Meeting. Mexico City.

Van Epps, G.A. 1975b. Winter injury to fourwing saltbush. J. Range Manage. 28:157-159.
Van Epps, G.A., and C.M. McKell. 1977. Shrubs plus grass for livestock forage: a possibility. Utah Sci. 38:75-78.

Van Epps, G.A., and C.M. McKell. 1978. Major criteria and proced ures for selecting and establishing range shrubs as rehabilitators of disturbed lands. p. 352-354. In: Proc. First Internat. Rangeland Congr. Hyder, D.N. (ed.). Soc. Range Manage. Denver, Colo.

Welch, B.L. 1978. Relationship of soil salinity, ash, and crude protein in Atriplex canescens. J. Range Manage. 31:132-133.

Welch, B.L., and S.B. Monsen. 1981. Winter crude protein differences among accessions of fourwing saltbush grown in a uniform garden. Great Basin Natur. 41:343-346.

Woolf, C.M. 1968. Principles of biometry. D. Van Nostrand Company, Inc. Princeton, N.I.

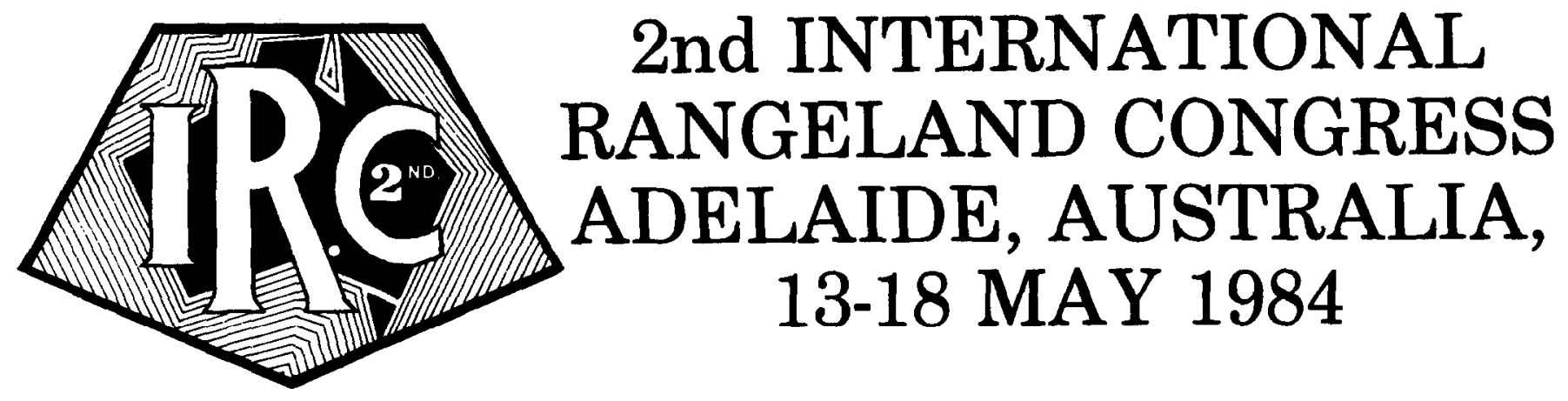

Contributions are sought for the following Symposia:

Dynamics of Range Ecosystems

Grazing Industries

Range Resources Monitoring and

Administration

Ecophysiology of Rangeland Plants

Mining and Rangelands

Conservation and Wildlife

Fire in Arid and Semi-arid Regions

Technological Improvement of Arid Rangelands

Animal Production Management of Grazing

Systems

Developing World-Challenges and Opportunities

MAB 3

Note: A Symposium will also be convened for primary producers (ranchers).

Pre- and post-Congress tours are being arranged to take in various aspects of Australia's rangelands.

Intending participants should write to Mr. P.J. Joss, CSIRO, Deniliquin, 2710, Australia. [Telex AA 55457]. 